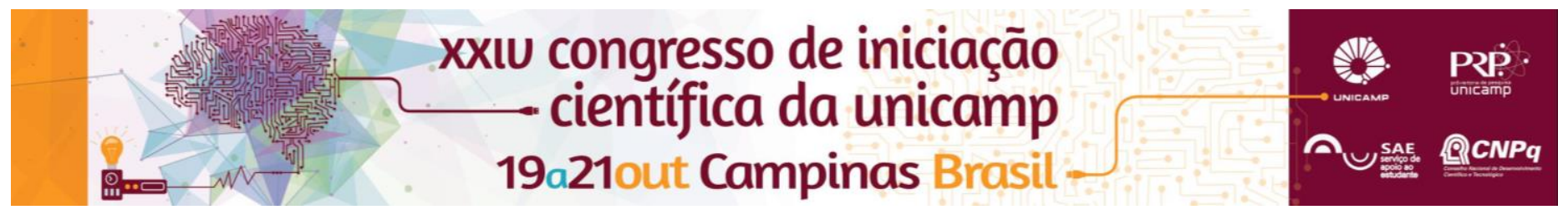

\title{
Mineral Amazon - Carajás and Serra Pelada in the historical relationship of the regional development and their environmental consequences.
}

\author{
Bruna Maria Cruz Fernandes*, Marko Synésio Alves Monteiro.
}

\begin{abstract}
Serra Pelada and Carajás, two of the biggest mining fields of high quality and easy exploration in Brazil, were targets of predatory mining in distinct historical moments. In this work we analyzed the impacts in the region due to these explorations. In the contest of a lack of environmental and social conscience, the explorations were not so well planned and therefore lead to one of the most problematic social and environmental frictions of the country. Although mining activity has its share of the responsibility regarding negative impacts, nowadays the idea of sustainability is one of the most important bases to lead to a mining exploration.
\end{abstract}

\section{Key words:}

Serra Pelada, Carajás, Mining Exploration

\section{Introduction}

The main objective of this work was to understand the regional development of Carajás and Serra Pelada, analyzing the environmental and social consequences due to mining exploration. These two sites were chosen because they were and still are examples of predatory exploration, with very significant and long term negative impacts. The analyses of these examples show that mining activity should be well planned, considering the economic, social and environmental impacts in mining sites, in order to avoid the same fate of the two sites discussed here.

The great dimension, population deficit and the distance between "the national centers of economic and and political command" (Barcellos \& Lima, 2002, free translation) of these places were seen in the 70's as an opportunity to test new ways of occupation.

In the 80's the political-economic and territorial structure of Amazon Rainforest was highlighted in the governmental agenda. The first intervention was the Carajás Iron Ore Project (Projeto Ferro Carajás, PFC), with the objective to bring investors to Amazon Rainforest (Da Silva, 2009). Due to the type of the activities that were implemented, today the region is one of the most problematic, social and environmentally, regions of the country.

\section{Results and Discussion}

Brazil followed the bad historical example of more developed countries, considering the predatory way we planned to extract the raw material, with negative effects until the present. According to Barcellos \& Lima (2002), $11 \%$ of Legal Amazon was deforested in the end of the 90's and according to Fonseca, Justino, Souza Jr \& Veríssimo (2016) $288 \mathrm{~km}^{2}$ were deforested in 2015.

The bibliographic research showed that the mining is not the main source of deforestation in the region, being livestock and agricultural activities the main source of the impact (Barcellos \& Lima, 2002).

However, this doesn't mean that mining is free of collateral damages. This activity has also created lots of impacts: pollution (soil, noise, water, so on), disorganized urban growth and a harmful dependent economy, based on the exportation of commodities with low added value, without further investments in innovation and national technology.

DOI: 10.19146/pibic-2016-50758
Nowadays, changes can be noted, in the enterprises as well as in the legislation, in the way to foment a more sustainable, social and environmental, mining.

\section{Conclusions}

Serra Pelada must be seen as an example for all the futures mining explorations, so that won't be this brutal and rapid, considering an enormous amount of soil with gold, that was formed millions of years ago, and was devastated in few years of human activity. And Carajás should show that the counties related with this activity, must have their own kinds of economic incentives, where they don't become too dependent on mining activity.

In general, in both cases, the environmental and social devastation is evident. Such reports must be seen in a way that future projects walk in parallel with the social development and environmental care that they deserve. The beginning of each and any mining exploration is essential to know which path they are going to take.

\section{Acknowledgement}

I would like to thank my parents, Maria Fernanda and Ronaldo Fernandes, because they always encouraged my best qualities. My friends that always could hang out with me, so I could keep calm and keep all things in the right places. And to Prof. Marko Synésio for all his patience to guide me on this first research, mainly when I was confused.

Barcellos, E. A. Mineração e desflorestamento na Amazônia Legal. In Jornada de Iniciação Científica, 10, Rio de Janeiro. Rio de Janeiro: CETEM/MCT, 2002.

Da Silva, J. M. P. Território e mineração na Amazônia paraense norte do Brasil. XII Encuentro de Geogrados da América Latina: Caminando em una America Latina em Transformación. Montevideo, Uruguay.

Fonseca, A.; Justino M.; Souza Jr., C. e Veríssimo, A. Amazônia Legal. Transparência Florestal. Janeiro, 2016 